\title{
Neutralization of cholera toxin by Rosaceae family plant extracts
}

Magdalena Komiazyk ${ }^{1,2}$, Malgorzata Palczewska ${ }^{2,3}$, Izabela Sitkiewicz ${ }^{4}$, Slawomir Pikula and Patrick Groves ${ }^{2,5^{*}}$ (D)

\begin{abstract}
Background: Cholera is one of the most deadly diarrheal diseases that require new treatments. We investigated the neutralization of cholera toxin by five plant extracts obtained from the Rosaceae family that have been traditionally used in Poland to treat diarrhea (of unknown origin).

Methods: Hot water extracts were prepared from the dried plant materials and lyophilized before phytochemical analysis and assessment of antimicrobial activity using microdilution assays. The ability of the plant extracts to neutralize cholera toxin was analyzed by measurement of cAMP levels in cell cultures, enzyme-linked immunosorbent assay and electrophoresis, as well as flow cytometry and fluorescence microscopy studies of fluorescent-labeled cholera toxins with cultured human fibroblasts.

Results: The antimicrobial assays displayed modest bacteriostatic potentials. We found that the plant extracts modulate the effects of cholera toxin on intracellular CAMP levels. Three plant extracts (Agrimonia eupatoria L., Rubus fruticosus L., Fragaria vesca L.) suppressed the binding of subunit B of cholera toxin to the cell surface and immobilized ganglioside $\mathrm{GM}_{1}$ while two others (Rubus idaeus L., Rosa.canina L.) interfered with the toxin internalization process.

Conclusions: The traditional application of the Rosaceae plant infusions for diarrhea appears relevant to cholera, slowing the growth of pathogenic bacteria and either inhibiting the binding of cholera toxin to receptors or blocking toxin internalization. The analyzed plant extracts are potential complements to standard antibiotic treatment and Oral Rehydration Therapy for the treatment of cholera.
\end{abstract}

Keywords: Cholera toxin, Diarrhea, Herbal remedies, Plant extracts, Rosaceae

\section{Background}

Diarrhea causes millions of deaths each year as a result of the action of a wide range of pathogens, including enterotoxin-producing strains of bacteria such as Escherichia coli or Vibrio cholerae [1]. The pathogens are mainly spread by water or food contaminated with human or animal feces, and from person to person. The $V$. cholerae infections result in severe diarrhea that, without proper treatment, can kill within a few hours. Children and the elderly in developing countries constitute the largest groups of fatalities. Cholera outbreaks are related to poor sanitation and usually occur after cataclysm or

\footnotetext{
* Correspondence: p.groves@ug.edu.pl

2Laboratory of Molecular Interactions and NMR, Instituto de Tecnologia Química e Biológica, Av. da República, 2780-157 Oeiras, Portugal

${ }^{5}$ Department of Biomedicinal Chemistry, Chemistry Faculty, University of

Gdansk, ul. 63 Wita Stwosza Street, 80-308 Gdańsk, Poland

Full list of author information is available at the end of the article
}

during a war when access to clean water is limited. The most recent cholera outbreak started in October 2016 in Yemen. Over 8 months, 101,820 cases of cholera were registered with 791 deaths [2]. In developed countries, only sporadic, often imported cases of $V$. cholerae infection occur [3-5] but diarrhea from pathogenic E. coli strains producing similar toxins regularly result in thousands of hospital patients, for example a 2011 outbreak affecting Germany and its' neighboring countries also resulted in 50 deaths [6]. The E. coli infections are usually not as dangerous as cholera but still cause many problems, especially for travelers, children and the elderly [1]. The main virulence factor of the above-mentioned bacteria is the production of toxins belonging to the $\mathrm{AB}_{5}$ family, such as cholera (CTX) or heat-labile enterotoxins (LT and LT-II). The toxins are expressed and secreted as a response to bacterial quorum sensing once a colony

(c) The Author(s). 2019 Open Access This article is distributed under the terms of the Creative Commons Attribution 4.0 International License (http://creativecommons.org/licenses/by/4.0/), which permits unrestricted use, distribution, and reproduction in any medium, provided you give appropriate credit to the original author(s) and the source, provide a link to the Creative Commons license, and indicate if changes were made. The Creative Commons Public Domain Dedication waiver (http://creativecommons.org/publicdomain/zero/1.0/) applies to the data made available in this article, unless otherwise stated. 
has reached a mature size [7]. Structurally, the $A B_{5}$ toxins contain a catalytic subunit $A_{1}$ linked by a short $A_{2}$ peptide to a pentameric subunit $\mathrm{B}$ that binds to gangliosides located on human cell surfaces [8]. After secretion from the bacteria, the toxin binds to gangliosides and is then internalized from the plasma membrane by endocytosis and undergoes retrograde trafficking through the trans-Golgi network to the lumen of the endoplasmic reticulum. Here, subunit A is dissociated from the holotoxin, refolded and released to the cytoplasm where it causes constitutive activation of adenylate cyclase, resulting in activation and the conversion of ATP to cAMP. The high concentration of cAMP results in the opening of cAMP-dependent chloride channels and secretion of chloride ions into the lumen of the small intestine. Accumulation of chloride causes secretion of sodium ions into the lumen of the small intestine across the tight junction. An increased concentration of sodium chloride in the small intestine lumen creates an osmotic gradient that results in water outflow into the small intestine lumen across the tight junction [9]. This is the point when diarrheal symptoms start. Table 1 gives a list of different stages of $V$. cholerae infection where a pharmaceutical intervention may provide relief of cholera symptoms/infection. Each stage involves a number of potential molecular targets. It is possible to block the multi-step mechanism of action of cholera toxin at several different stages. Toxin neutralization after release by the bacteria and before internalization by human cells is one of the most accessible targets for a natural remedy or functional food to act on, and these stages are highlighted in bold in Table 1. Targeting a protein in human cells (italics, Table 1) is more challenging and more difficult to gain approval while the targeting of bacteria (normal text, Table 1) raises questions due to the growing knowledge of the importance of the diversity and health of the gut microbiome.

Various plant species are traditionally used by many societies to alleviate and cure diarrhea. The properties of traditional plant extracts are worth exploring as they can stop or kill bacterial growth, neutralize or deactivate enterotoxins, or provide useful microelements and vitamins [23]. Over the years, the healing properties of many plants have been superseded by synthetic pharmaceuticals, often derived from the active constituents of plants. Bacterial pathogens are becoming more resistant to commonly applied antibiotics and it is important to find new sources of antibacterial agents. However, this is unattractive in the case of cholera due to the development costs of a new drug and the fact that the disease can develop rapidly in a patient. Plant extracts do not provide the power of modern antibiotics. Instead, plant extracts may provide an attenuation of the many steps in the $V$. cholerae infection lifecycle, including the latent, early stages of the disease, moderate the effects of diarrhea and lead to improved survival and recovery rates. The citations given in Table 1 are to works describing the methodology to test plant extracts at each stage of the cholera infection, with the exception of the quorum sensing stage that used a small molecule library. If we can identify plant extracts that act at different stages of the $V$. cholerae infection lifecycle then it is possible that mixtures of plant extracts will provide a synergistic effect on the infected population, as well as individuals. This may help patients at different stages of infection, including asymptomatic carriers. The range of active

Table 1 Stages of $V$. cholerae infection

\begin{tabular}{|c|c|c|c|}
\hline Stage/Action ${ }^{a}$ & Test methods & Active plant extracts & reference \\
\hline 1. Initial anchoring & $\begin{array}{l}\text { Anti-adherence } \\
\text { Anti-invasion }\end{array}$ & Aegle marmelos & [10] \\
\hline 2. Stress induction & Luminescent assay & Several plant extracts, including Rosmarinus officinalis & [11] \\
\hline 3. Bacteriostatic & Various & Various & e.g. $[10,12-14]$ \\
\hline \multicolumn{4}{|l|}{ 4. Bacteriocidal } \\
\hline 5. Quorum sensing & Native bioluminescence & Small molecule screen & [15] \\
\hline 6. CTX expression and secretion & $\begin{array}{l}\text { rtPCR } \\
\text { ELISA of Cell free culture supernatant }\end{array}$ & $\begin{array}{l}\text { Capsaicin } \\
\text { Several plants }\end{array}$ & [16] [17] \\
\hline 7. CTX disassembly & PAGE & (-)-Epicatechin from Chiranthodendron pentadactylon & [19] \\
\hline 8. CTX aggregation & Centrifugation, PAGE & Plant derived polyphenols & [18] \\
\hline 9. Inhibition of $\mathrm{GM}_{1}$ binding & $\mathrm{GM}_{1}$ ELISA & Screening of 297 Chinese herbs & [19] \\
\hline 10. Intracellular trafficking & Biotinlabeled CTX based assay & Resveratrol - found in red grapes, berries and peanuts & [20] \\
\hline \multicolumn{4}{|l|}{ 11. CTA inhibitor } \\
\hline 12. Channel blocker & Patch clamp & Mixture including agarwood and clove & [21] \\
\hline 99. Taste ${ }^{b}$ & Patient based & apple & [22] \\
\hline
\end{tabular}

${ }^{a}$ The stages can be grouped based on bacterial target (normal text), extracellular toxin target (bold) and human cell target (italics)

${ }^{\mathrm{b}}$ The taste of ORT might be an important factor for the treatment of under-fives 
metabolites produced by plants potentially treats a broad range of pathogenic strains and it will be more difficult for bacteria to develop resistance than with modern antibiotics. Furthermore, plant extracts based on accepted traditional medicines or functional foods will be more quickly, and cheaply, developed and applied.

In this study, we focus on the anti-enterotoxic activities of common European species belonging to the Rosaceae family: Agrimonia eupatoria L. (common agrimony), Fragaria vesca L. (wild strawberry), Rubus fruticosus L. (blackberry), Rubus idaeus L. (raspberry) and Rosa canina L. (rose), which for centuries were used in Poland as natural medicines for diarrhea [24-28]. The recommended doses, methods of infusion preparation and references are listed in Table 2. Neither the pathogenic target of these herbs is known, nor their mechanism of action. However, Poland suffered from regular cholera outbreaks in the 19th and early 20th centuries [29], and sporadic cases are still reported with non-O1 $V$. cholerae strains found in contaminated bodies of water [5]. Therefore, in this study, we wanted to analyze if the above-mentioned plant extracts have antimicrobial activities and/or can neutralize cholera toxin binding to receptors. In doing so, we obtained some positive results and also found that assays employing CTX gave less positive results than CTB.

\section{Methods}

\section{Plant material and extraction}

The plants were dried from their natural state, and cut or chopped. All plant materials were authenticated and tested to comply with British and European food/ pharmacopeia standards by the supplier, Bristol Botanicals Limited (Bristol, UK). The list of the used species and batch numbers are presented in Table 3. The aqueous extracts were prepared by pouring $25 \mathrm{~mL}$ of boiling Milli-Q (MQ) grade water onto $1 \mathrm{~g}$ of plant material, allowed to cool to room temperature, and left to stand for over $18 \mathrm{~h}$. The extracts were decanted and passed consecutively through filter paper and $0.4 \mu \mathrm{m}$ cellulose acetate filters (Whatman, UK). To further minimize contamination or degradation, the plant extracts were frozen and lyophilized to dryness, after which the extraction yields were calculated (Table 3), and then stored at $-20^{\circ} \mathrm{C}$. The lyophilized materials gave consistent data over several months.

\section{Mammalian cell culture}

Primary human skin fibroblasts (line C688) were obtained from the Department of Metabolic Diseases, The Children's Memorial Health Institute in Warsaw, Poland [30]. Ganglioside $\mathrm{GM}_{1}$ molecules, receptors for CTX, are one component of fibroblast membranes. C688 cells were cultured in Dulbecco's Modified Eagle's Medium (DMEM) (Sigma, USA) with $10 \%$ fetal bovine serum (FBS, Gibco, South America), 100 units $/ \mathrm{mL}$ penicillin and $100 \mu \mathrm{g} / \mathrm{mL}$ streptomycin (Sigma, USA) at $37^{\circ} \mathrm{C}$ in a humidified atmosphere containing $5 \% \mathrm{CO}_{2}$, on $100 \mathrm{~mm}$ tissue-culture treated dishes (Corning $\mathrm{BD}$, USA) until 80-90\% confluence. To dissociate the adherent cells, dishes were rinsed with phosphate buffered saline solution pH 7.5 (PBS, $10 \mathrm{mM} \mathrm{Na}_{2} \mathrm{HPO}_{4}, 1.76 \mathrm{mM} \mathrm{KH}_{2} \mathrm{PO}_{4}$, $2.7 \mathrm{mM} \mathrm{KCl}, 136 \mathrm{mM} \mathrm{NaCl}$ ) and incubated with $2 \mathrm{~mL}$ $(0.5 \mathrm{mg} / \mathrm{mL})$ of porcine trypsin (Sigma, USA) for $7 \mathrm{~min}$ at $37^{\circ} \mathrm{C}$. Cells were collected by centrifugation $(500 \mathrm{~g}$ for $3 \mathrm{~min}$ ), resuspended in fresh medium and counted under a light microscope (Zeiss Observer Z1, Germany) using a Bürker chamber.

\section{Cytotoxic effect of plant extracts (MTT method)}

The cytotoxic activity of plant extracts was determined using the standard MTT method (according to a Sigma protocol). We seeded $5 \times 10^{3} \mathrm{C} 688$ cells/well into 96 well plates and cultured them as described above. The next day, the medium was discarded and cells were treated with $200 \mu \mathrm{L}$ of several different concentrations of plant extracts diluted in DMEM with 1\% FBS (range 5 to $0.078 \mathrm{mg} / \mathrm{mL}$ ). After $24 \mathrm{~h}$ incubation at $37^{\circ} \mathrm{C}$, the medium was discarded and wells were washed twice in PBS, pH 7.5. To determine cell viability, $20 \mu \mathrm{L}$ of $5 \mathrm{mg} /$

Table 2 Traditional preparation of plant infusions for the treatment of diarrhea in Poland

\begin{tabular}{|c|c|c|c|c|c|c|c|c|}
\hline Plant & $\begin{array}{l}\text { Common } \\
\text { Name }\end{array}$ & $\begin{array}{l}\text { Used } \\
\text { part }\end{array}$ & $\begin{array}{l}\text { dry material } \\
\text { weight [g] }\end{array}$ & $\begin{array}{l}\text { Added } \\
\text { water }[\mathrm{mL}]\end{array}$ & $\begin{array}{l}\text { Concentration } \\
\text { (g) / liter }\end{array}$ & Infusion preparation & $\begin{array}{l}\text { Daily oral } \\
\text { doses }\end{array}$ & References \\
\hline $\begin{array}{l}\text { Agrimonia } \\
\text { eupatoria L. }\end{array}$ & agrimony & $\begin{array}{l}\text { aerial } \\
\text { parts }\end{array}$ & $1.5-4$ & $\leq 250$ & $6-16$ & \multirow{5}{*}{$\begin{array}{l}\text { The stated amount of boiling water } \\
\text { is poured over the dry plant powder, } \\
\text { covered and incubated for } 15 \text { min to } 8 \mathrm{~h}\end{array}$} & $2-3$ & {$[26,27]$} \\
\hline $\begin{array}{l}\text { Rubus fruticosus } \\
\text { L. }\end{array}$ & blackberry & leaves & $1-2$ & 250 & $4-8$ & & $3^{b}$ & {$[28]$} \\
\hline Rubus idaeus L. & raspberry & leaves & $1.5-8$ & 150 & $10-53.3$ & & $2-3$ & {$[25,27]$} \\
\hline Rosa canina L. & rosehip & fruit & $2-5$ & 150 & $13.3-33.3$ & & $\geq 3$ & {$[24,27]$} \\
\hline Fragaria vesca $\mathrm{L}$. & $\begin{array}{l}\text { wild } \\
\text { strawberry }\end{array}$ & leaves & $1-2$ & 250 & $4-8$ & & $3^{b}$ & {$[27,28]$} \\
\hline
\end{tabular}

${ }^{a}$ Equivalent amount of dry plant material per liter of hot water to produce a traditional preparation

${ }^{\mathrm{b}}$ Recommended dose for children is $80-125 \mathrm{~mL}$ 
Table 3 Yields of prepared plant extracts

\begin{tabular}{|c|c|c|c|c|c|c|}
\hline Latin Name & Common Name & Used part & Batch number & $\%$ yield & Concentration $(\mathrm{g}) /$ liter $^{\mathrm{a}}$ & cytotoxicity (IC 50) [mg/mL] \\
\hline Agrimonia eupatoria L. & agrimony & aerial parts & MHSO02/ 110,324 & 12.6 & 19.8 & 5 \\
\hline Rubus fruticosus $\mathrm{L}$. & blackberry & leaves & MHS016/ 100,621 & 14.2 & 17.6 & 2.5 \\
\hline Rubus idaeus L. & raspberry & leaves & MHS121/ 177,905 & 19.4 & 12.9 & 2.5 \\
\hline Rosa canina $\mathrm{L}$. & rosehip & rosehip (fine cut) & MHS125/ 7640 & 29.5 & 8.5 & $>10$ \\
\hline Fragaria vesca $\mathrm{L}$. & wild strawberry & leaves & MHS144/ 184,439 & 11.3 & 22.1 & 2.5 \\
\hline
\end{tabular}

a equivalent amount of dry plant material per liter of hot water to produce a $2.5 \mathrm{mg} / \mathrm{mL}$ plant extract concentration

mL MTT ((3-[4,5-dimethylthiazol-2-yl]-2,5-diphenyltetrazolium bromide), Sigma, USA) in PBS and $180 \mu \mathrm{L}$ of DMEM without FBS were added to the wells and incubated for $4 \mathrm{~h}$ at $37^{\circ} \mathrm{C}$. Then, the medium was carefully discarded and $200 \mu \mathrm{L}$ of $40 \mathrm{mM} \mathrm{HCl}$ in isopropanol was added. After $10 \mathrm{~min}$ incubation, the absorbance was measured at $570 \mathrm{~nm}$ with the background wavelength set to $630 \mathrm{~nm}$ using a SpectraMax M5 ${ }^{\mathrm{e}}$ plate reader. All experiments were carried out in triplicate. The percentage of viable cells was calculated using Eq. 1:

$$
\% \text { viable cells }=A_{1} X 100 \% / A_{0}
$$

where $A_{0}$ is the value of the absorbance for control conditions (which was considered 100\%) and $A_{1}$ is the value of the absorbance for tested samples, reduced by the value of background.

\section{Microbial strains}

The aqueous plant extracts were tested against four bacterial strains: Escherichia coli ATCC 25922, E. coli O44 (834/04, collection of National Medicine Institute, Warsaw, Poland), Vibrio cholerae O395-tacCTB strain (Chiron Srl./Novartis) and Lactobacillus rhamnosus (ATCC 53103).

\section{Broth microdilution assay}

The antimicrobial activity of plant extracts was determined by a standard microdilution technique using 96well microtiter plates. Bacterial inoculates were prepared from $12 \mathrm{~h}$ liquid cultures grown on Mueller-Hinton $(\mathrm{MH})$ broth. The plant extracts were dissolved in $\mathrm{MH}$ medium to a concentration of $2.5 \mathrm{mg} / \mathrm{mL}$ and a series of six, two-fold dilutions of plant extracts in $\mathrm{MH}$ broth (range $2.5-0.078 \mathrm{mg} / \mathrm{mL}$ ) were prepared across the microtiter plates. To each well, $10 \mu \mathrm{L}$ of inoculum $(\sim 0.2 \times$ $10^{5}$ bacterial cells / well) was added. The wells were filled with $\mathrm{MH}$ broth to $200 \mu \mathrm{L}$ total volume. As a negative control, plant extracts were replaced with $\mathrm{MH}$ broth and as a positive control - bacteria were incubated with $35 \mu \mathrm{g} / \mathrm{mL}$ of chloramphenicol. After $18 \mathrm{~h}$ incubation at $37^{\circ} \mathrm{C}$, the absorbance of each well was measured at 600 $\mathrm{nm}$ using a SpectraMax $\mathrm{M}^{\mathrm{e}}$ plate reader. The bacterial growth was calculated with Eq. 2: \%bacterial growth $=\mathrm{A}_{1} \mathrm{X} 100 \% / \mathrm{A}_{0}$

where $\mathrm{A}_{1}=$ sample absorbance, $\mathrm{A}_{0}=$ absorbance of negative control.

Using this scale, $0 \%$ is total bacterial growth inhibition and $100 \%$ is the bacterial growth in the absence of plant extracts. The plant extract concentration that resulted in a bacterial growth reduction by more than $80 \%$ was interpreted as a minimal inhibitory concentration (MIC), while a reduction by more than $50 \%$ was defined as a concentration that limited bacterial growth.

To determine the minimal bactericidal concentrations (MBC) of the plant extracts, $2 \mu \mathrm{L}$ of suspension after 18 $\mathrm{h}$ culture was applied to $\mathrm{MH}$ agar plates and cultured at $37^{\circ} \mathrm{C}$ for $18 \mathrm{~h}$. The lowest concentration of plant extract without bacterial colonies was interpreted as the MBC. The experiments were performed in triplicate.

\section{cAMP assay}

The cAMP levels in cultured C688 cells were determined using a cAMP-Glo Max Assay (Promega, USA), according to the manufacturer's protocol. Cells were grown in tissue culture treated 96-well, white plates with clear, flat bottoms (Brand, Germany). To each well, $10^{3}$ C688 cells were added and cultured overnight under standard conditions. The next day, the medium was discarded and a mixture of $2.5 \mathrm{mg} / \mathrm{mL}$ plant extract or gallic acid and $25 \mathrm{nM}$ CTX $(2.125 \mu \mathrm{g} / \mathrm{mL})$ in DMEM supplemented with $30 \mathrm{mM} \mathrm{MgCl} 2$ was added to each well. The plates were incubated for $2 \mathrm{~h}$ at $37^{\circ} \mathrm{C}$ in $5 \%$ $\mathrm{CO}_{2}$. Next, the proper amount of detection solution and kinase glo reagent were added. The luminescence (RLU) was measured using a SpectraMax $\mathrm{M}^{\mathrm{e}}$ plate reader. As controls, cells were incubated with only: plant extracts, CTX, or DMEM. The cAMP level was calculated as a change in RLU ( $\triangle R L U)$ for the sample incubated with only plant extract/gallic acid/DMEM and the sample incubated with a mixture of plant extract/gallic acid/DMEM and CTX. Each sample was tested in three repeats.

\section{Ganglioside $\mathrm{GM}_{1}$ - CTX binding assay}

The ganglioside $\mathrm{GM}_{1}$ - CTX interaction was analyzed according to a published protocol based on the ELISA method ([18], with modification). The 96-well, clear, flat- 
bottom immune-plates (Nunc, Denmark) were coated with $25 \mathrm{ng}$ ganglioside $\mathrm{GM}_{1}$ resuspended in $50 \mu \mathrm{L}$ ethanol and incubated at $37^{\circ} \mathrm{C}$ for $2 \mathrm{~h}$, to dryness. The wells were washed three times with $200 \mu \mathrm{L}$ wash buffer $(0.05 \%$ Tween 20 in PBS, pH 7.5), blocked with $200 \mu \mathrm{L}$ blocking buffer (0.5\% bovine serum albumin (BSA, Sigma, USA) in PBS) for $18 \mathrm{~h}$ at $4{ }^{\circ} \mathrm{C}$, and washed three more times with $200 \mu \mathrm{L}$ wash buffer. Wells coated with ganglioside $\mathrm{GM}_{1}$ were incubated with $2.5,1.25,0.625,0.3,0.15$, $0.075 \mathrm{mg} / \mathrm{mL}$ of plant extracts and $0.25 \mu \mathrm{g} / \mathrm{mL}$ CTX for $2 \mathrm{~h}$, in a total volume $200 \mu \mathrm{L}$. As negative controls, three wells coated with $\mathrm{GM}_{1}$ were incubated with CTX to provide maximal measurements or with $2.5 \mathrm{mg} / \mathrm{mL}$ plant extract to provide baseline measurements. To prepare a positive control, the binding sites of CTB were blocked with free $\mathrm{GM}_{1}$ as an inhibitor, by pre-incubating CTX with $\mathrm{GM}_{1}$ for $1 \mathrm{~h}$. The resulting, inactivated CTX was added to wells coated with $\mathrm{GM}_{1}$ and incubated as described above. The wells were washed three times with $200 \mu \mathrm{L}$ of wash buffer followed by incubation with $50 \mu \mathrm{L}$ of anti-CTB antibody (Invitrogen), diluted 1:4000 in $0.5 \%$ bovine serum albumin (BSA), for $90 \mathrm{~min}$ at room temperature. After triple washing, wells were incubated for $75 \mathrm{~min}$ at room temperature with $50 \mu \mathrm{L}$ of secondary anti-mouse antibody conjugated with horse radish peroxidase (Sigma), diluted 1:15,000 in 0.5\% BSA. Wells were washed three times with wash buffer, once with PBS and then dried. To visualize the CTX bound to $\mathrm{GM}_{1}, 100 \mu \mathrm{L}$ 3,3',5,5' -Tetramethylbenzidine (Millipore, USA) was added to each well and incubated for $15 \mathrm{~min}$. To stop the reaction, $100 \mu \mathrm{L}$ of stop solution $(0.5 \mathrm{M}$ $\mathrm{H}_{2} \mathrm{SO}_{4}$ ) was added and the absorbance was measured at $450 \mathrm{~nm}$ using a SpectraMax M5 ${ }^{\mathrm{e}}$ plate reader. Each assay was repeated six times.

\section{Ganglioside $\mathrm{GM}_{1}$ and CTB-FITC binding assay}

The protocol to this method is similar as for CTX (above). Instead of unlabeled CTX, $1.25 \mu \mathrm{g} / \mathrm{mL}$ of CTBFITC (Sigma, Israel), CTB labeled with a fluorescent fluorescein derivative, was incubated with the appropriate concentration of plant extracts $(2.5-0.075 \mathrm{mg} / \mathrm{m}$, serial dilutions) in a total volume of $200 \mu \mathrm{L}$. After $2 \mathrm{~h}$ incubation at room temperature, wells were washed three times with PBS. Next, $200 \mu \mathrm{L}$ of PBS was added and the intensity of fluorescence was measured at $490 \mathrm{~nm}$ excitation and $525 \mathrm{~nm}$ emission, using an Infinite M1000 PRO plate reader (Tecan). Each assay was repeated six times.

\section{Fluorescence activated cell sorting (FACS) assay: quantitative assay}

This assay was performed to analyze the ability of plant extracts to inhibit the binding of CTB-FITC to ganglioside $\mathrm{GM}_{1}$ naturally embedded in the extracellular surfaces of fibroblasts (C688). C688 cells $\left(5 \times 10^{4}\right)$ were re-suspended in DMEM and incubated for $60 \mathrm{~min}$ at $37{ }^{\circ} \mathrm{C}$ with $2.5 \mathrm{mg}$ plant extract and $0.25 \mu \mathrm{g}$ CTB-FITC in $1 \mathrm{~mL}$ total volume. As controls, we used: (i) cells exposed only to toxin, which was treated as a negative control, (ii) cells exposed only to plant extract, which allowed us to account for autofluorescence from the plant extract and (iii) cells treated with inactivated FITC-CTB, obtained by pre-incubation of $0.5 \mu \mathrm{g} / \mathrm{mL}$ $\mathrm{GM}_{1}$ and $0.25 \mu \mathrm{g} / \mathrm{mL}$ FITC-CTB for $1 \mathrm{~h}$, which was treated as a positive control. To all samples, $50 \mu \mathrm{g} / \mathrm{mL}$ propidium iodide (PI, Sigma, USA) was added to determine cell viability. The number of stained cells and the intensity of the fluorescence of $10^{4}$ cells were analyzed by flow cytometry (FACSCalibur, Becton Dickinson, USA) in two channels: FL-1 (green) for FITC and FL-3 (red) for PI. The data were analyzed using CellQuest acquisition/analysis software. Each sample was tested in three independent assays.

\section{Fluorescent microscopy - qualitative assay}

This assay was performed to visualize the activity of the plant extract and CTB-FITC on cells containing ganglioside $\mathrm{GM}_{1}$. C688 cells $\left(5 \times 10^{3}\right)$ were seeded onto cover glass slips and cultured for $18 \mathrm{~h}$ according to the described procedure. Cells adherent to the glass were washed in PBS and incubated at $37^{\circ} \mathrm{C}$ for $1 \mathrm{~h}$ with 5.0, 2.5 or $1.25 \mathrm{mg} / \mathrm{mL}$ plant extract and $0.25 \mu \mathrm{g} / \mathrm{mL}$ CTBFITC in $500 \mu \mathrm{L}$ DMEM, and then fixed with $3 \%$ paraformaldehyde. The nuclei were stained with $0.3 \mathrm{mg} / \mathrm{mL}$ of 2-(4-Amidinophenyl)-6-indolecarbamidine dihydrochloride (DAPI, Sigma, Israel). The cover glass slips were stuck to microscope slides using MOVIOL solution and observed under a Fluorescent Microscope (Axio Observer $\mathrm{Z} 1$, Zeiss). Each sample was tested in three independent repeats.

\section{Discontinuous polyacrylamide gel electrophoresis under denaturing conditions (SDS-PAGE)}

Our protocol is based on a published method with some modifications [31]. CTX $(2 \mu \mathrm{g})$ was incubated with $1 \mathrm{mg}$ plant extracts in a twofold diluted range $(1-0.0015 \mathrm{mg})$ for $1 \mathrm{~h}$ at room temperature. The total sample volume was $12 \mu \mathrm{L}$. Next, samples were applied to $10 \%$ denatured gels and, using the Tris/Tricine discontinuous electrophoresis system ([32], with modifications), run for 90 min at $90 \mathrm{~V}(15 \mathrm{~min})$ and next at $130 \mathrm{~V}$. The gels were washed and stained with Blue BANDit Protein Stain reagent (VWR, USA). As a negative control, we used CTX without plant extracts. To avoid false positive results and eliminate thresholds we used plant extracts without CTX. As positive controls, CTX was incubated with ganglioside $\mathrm{GM}_{1}$ solution $(2-0.03 \mu \mathrm{g})$ and gallic acid $(0.1-0.0015 \mathrm{mg})$. The experiments were performed in triplicate 


\section{Statistical analyses}

Data were obtained from three or six measurements, as defined in the specific sections, and were expressed as the means \pm standard deviation. Statistical analyses were performed using one-way ANOVA, followed by the Bonferroni-Holm post hoc test [33]. Statistically significant differences between groups were defined as $p$-values less than 0.05 with the Bonferroni-Holm correction.

\section{Results}

\section{Preparation and preliminary characterization of plant extracts}

After hot water extraction and filtration, the lyophilized plant powders were stored at $-20^{\circ} \mathrm{C}$. The efficiency of the extraction process is shown for each plant species in Table 3. The yield varied between 11 and $19 \%$, but is almost $30 \%$ for rosehip. The results of the phytochemical analyses [34-36] of each aqueous extract are given in Additional file 1. The cytotoxic activity of all extracts was tested using the MTT method against C688 cells, Table 3. Concentrations above 2.5 $\mathrm{mg} / \mathrm{mL}$ of raspberry leaf, blackberry leaf and wild strawberry leaf were found to be cytotoxic, for agrimony this effect is above $5 \mathrm{mg} / \mathrm{mL}$, while the rosehip extract is not cytotoxic even at $10 \mathrm{mg} / \mathrm{mL}$.

\section{Antimicrobial activity tests}

The antimicrobial activity of plant extracts were analyzed using standard microdilution assays, stages 2 and 3 of Table 1. Bacteria were cultured with plant extracts in the concentration range $0.078-2.5 \mathrm{mg} / \mathrm{mL}$, and additionally at $10 \mathrm{mg} / \mathrm{mL}$. With an increased concentration of plant extracts, the $\mathrm{OD}_{600}$ of $18 \mathrm{~h}$ cultures decreased, which suggests that the plant extracts slow bacterial growth but did not reduce it by $80 \%$ (Fig. 1a). The 2.5 $\mathrm{mg} / \mathrm{mL}$ concentrations of each extract limited bacterial growth (Fig. 1b) but did not possess bactericidal activity against $V$. cholerae. When the concentration of the plant extracts were increased to $10 \mathrm{mg} / \mathrm{mL}$ (data not shown), bactericidal activity for agrimony and blackberry leaf extracts was observed. None of the tested plant extracts, even at $10 \mathrm{mg} / \mathrm{mL}$, inhibited the growth of Lactobacillus rhamnosus, which was chosen to represent beneficial gut bacteria. The $35 \mu \mathrm{g} / \mathrm{mL}$ of chloramphenicol, used as a positive control, has bactericidal activity for all of the tested bacteria species (it reduced the bacterial culture densities by more than $99 \%$ compared to untreated samples). Table 4 summarizes the antimicrobial results with significant data (effects at or below traditional doses) given in bold.

\section{Aqueous plant extracts reduce cAMP production}

The changes of cAMP levels in cell cultures were determined using the cAMP-Glo ${ }^{\mathrm{m}}$ Max Assay from Promega. This assay reports the cumulative effect of the plant extracts on stages 7-10 of Table 1 , as well as other possible intracellular effects not specified here. Treating cell cultures with cholera toxin resulted in larger cAMP concentrations in the cell, which then lead to a reduction in the luminescence intensity (RLU). The difference in

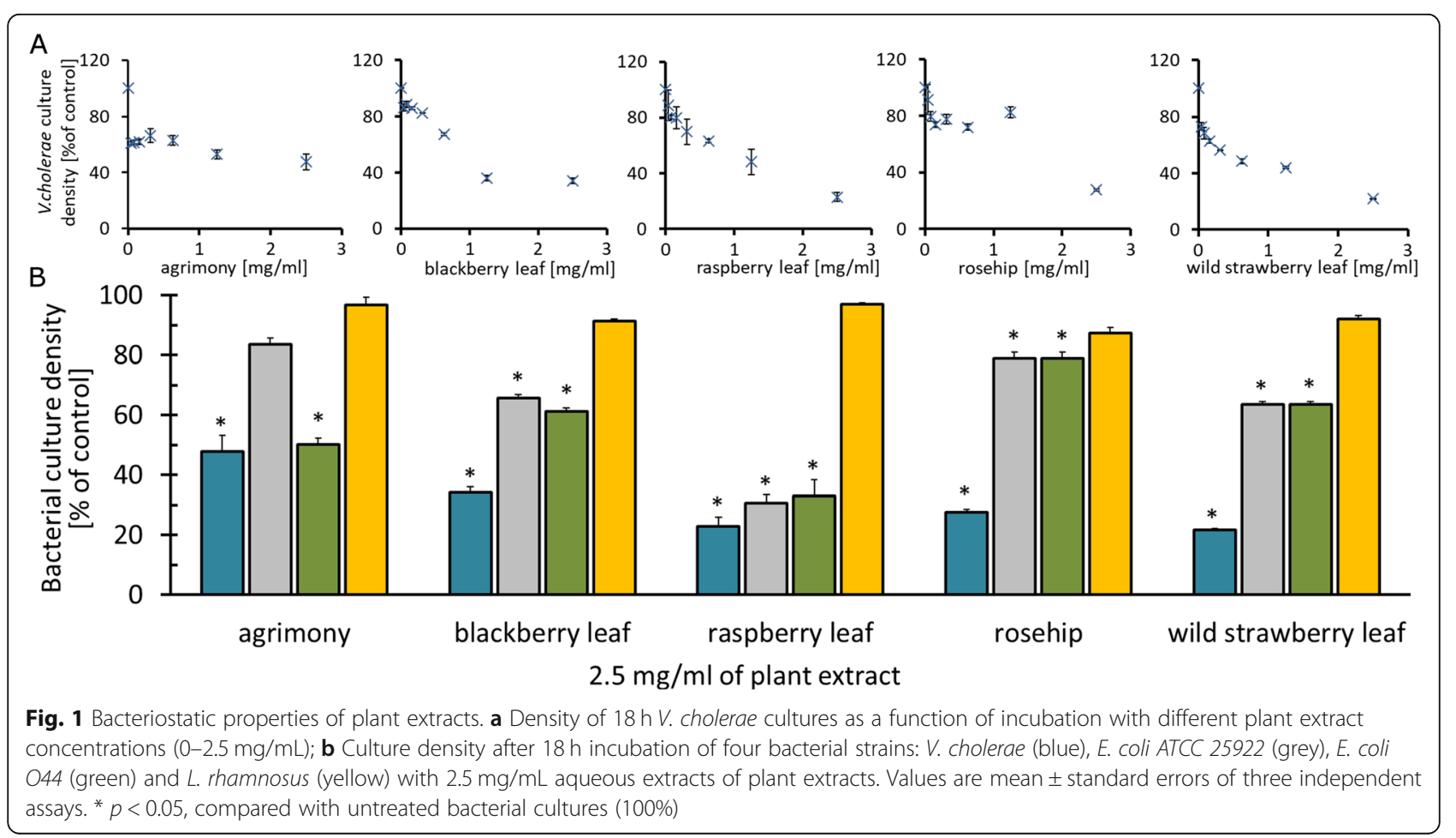


luminescence $(\Delta R L U)$ between untreated and cholera toxin treated cells was around 12,000 RLU, and this served as a control for plant extract or gallic acid treated samples (Fig. 2). The application of $2.5 \mathrm{mg} / \mathrm{mL}$ agrimony extract caused the reduction of cAMP levels by $70 \%$ compared to the control, while application of the same concentration of wild strawberry leaf, blackberry leaf, raspberry leaf and gallic acid reduced it by more than $90 \%$. The incubation with $10 \mathrm{mg} / \mathrm{mL}$ rosehip extract reduced the cAMP level by $65 \%$. These positive results indicate that the tested plant extracts interfere with the mechanism of action of cholera toxin to different extents and we decided to employ further tests to probe the roles of the different plant extracts.

\section{Aqueous plant extracts inhibit the binding of CTX and CTB to ganglioside $\mathrm{GM}_{1}$}

We next investigated if plant extracts inhibit the binding of cholera toxin to immobilized $\mathrm{GM}_{1}$ receptors, stages 8-9 of Table 1 . The inhibitory ability of Rosaceae extracts on the binding of CTB and CTX to ganglioside $\mathrm{GM}_{1}$ was evaluated by competitive $\mathrm{GM}_{1}$-ELISA, Figs. 3 and 4. The amount of CTX and CTB bound to $\mathrm{GM}_{1}$ in the presence of a fixed concentration $(2.5 \mathrm{mg} / \mathrm{mL})$ of plant extract is shown in Fig. 3 while the effect of variable plant extract concentrations on toxin binding to $\mathrm{GM}_{1}$ is given in Fig. 4 and Table 5. Each plant extract inhibits the binding of toxin to $\mathrm{GM}_{1}$ but the efficiency varies among plant extracts. The weakest suppression of the binding of toxin to $\mathrm{GM}_{1}$ was found to be rosehip extract (Fig. 4d). Incubation with $2.5 \mathrm{mg} / \mathrm{mL}$ of rosehip extract resulted in a $68 \%$ reduction in the binding of CTB but only a more modest $28 \%$ for CTX to the immobilized $\mathrm{GM}_{1}$. The minimal plant extract concentration necessary to inhibit $50 \%$ of the CTX bound to the $\mathrm{GM}_{1}$ for blackberry leaf (Fig. $4 \mathrm{~b}$ ) and raspberry leaf (Fig. 4c) was found to be $0.15 \mathrm{mg} / \mathrm{mL}$, while for agrimony (Fig. 4a) and wild strawberry leaf (Fig. 4e) it was found to be $0.3 \mathrm{mg} / \mathrm{mL}$

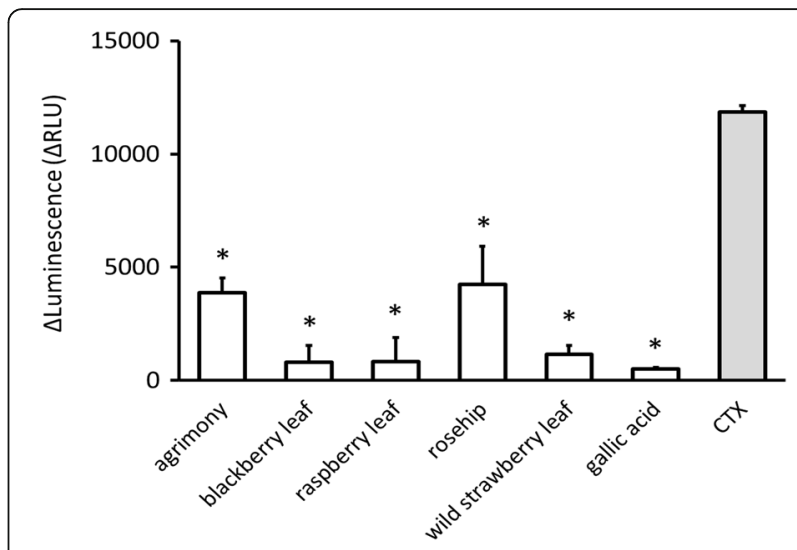

Fig. 2 Plant extracts modulate the increased cAMP concentrations caused by the addition of cholera toxin to cell cultures. Bioluminescent assay showing the differences ( $\Delta R L U$ ) between cAMP production by fibroblasts treated only with plant extracts $(2.5 \mathrm{mg} / \mathrm{mL}$ agrimony, blackberry leaf, raspberry leaf, wild strawberry leaf, gallic acid and 10 $\mathrm{mg} / \mathrm{mL}$ rosehip) and fibroblasts treated with plant extracts and CTX $(25 \mathrm{nM})$ (white). As a control, the difference between untreated and CTX treated cells is shown (grey). Values are mean \pm standard error of three independent assays. ${ }^{*} p<0.0023$, compared with control

\section{Aqueous plant extracts prevent CTB-binding to human fibroblasts}

CTB conjugated with a fluorophore is commonly used as a marker for lipid rafts, which are rich in gangliosides [37-39]. Exploiting this fact, the addition of CTB-FITC to human fibroblasts led to a strong fluorescent labeling of human C688 fibroblast cells, Figs. 5 and 6. Fluorescence cytometry gives a measure of CTB-FITC labeling of $\mathrm{C688}$ cells in the presence and absence of plant extracts (Fig. 5). This assay also tests stages 8 and 9 of Table 1. The addition of CTB-FITC resulted in a distinct change in the fluorescence labeling of C688 cells compared to the normalized background readings. A significant lowering of the number of CTB-FITC labeled C688 cells was observed after pre-incubation of CTB-FITC with the positive control, ganglioside $\mathrm{GM}_{1}$ (Fig. 5f). The pre-incubation of CTB-FITC with extracts of agrimony

Table 4 Concentration of plant extracts to reduce bacterial culture densities by $50 \%$

\begin{tabular}{|c|c|c|c|c|c|}
\hline \multirow[t]{2}{*}{ Extract } & \multicolumn{4}{|c|}{ Bacterial culture $^{c}$} & \multirow{2}{*}{$\begin{array}{l}\text { Bactericidal } \\
\text { potential }^{\mathrm{b}}\end{array}$} \\
\hline & V. cholerae ${ }^{a}$ & E. coli ATCC $25922^{a}$ & E. coli $044^{a}$ & L. rhamnosus & \\
\hline agrimony & 1.25 & 10 & 2.5 & $>10$ & $\mathrm{No}^{\mathrm{d}}$ \\
\hline blackberry leaf & 1.25 & 10 & $>10$ & $>10$ & $\mathrm{No}^{\mathrm{d}}$ \\
\hline raspberry leaf & 1.25 & 2.5 & 2.5 & $>10$ & No \\
\hline rosehip & 2.5 & $>10$ & $>10$ & $>10$ & No \\
\hline wild strawberry leaf & 0.625 & $>10$ & $>10$ & $>10$ & No \\
\hline
\end{tabular}

${ }^{\mathrm{a}}$ Entries in bold indicate effects at, or below, traditional doses

${ }^{\mathrm{b}}$ Tested against V. cholerae, E. coli ATCC 25922, E. coli 044 and L. rhamnosus

'Values in $\mathrm{mg} / \mathrm{mL}$ applied plant extract

${ }^{d}$ Bactericidal potential observed at $10 \mathrm{mg} / \mathrm{mL}$ levels, above Traditional concentrations 


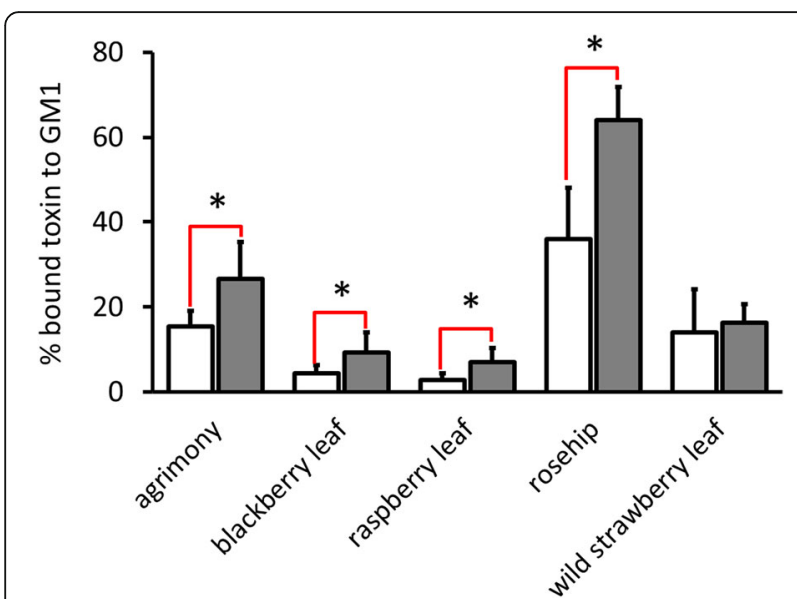

Fig. 3 Plant extract interference in the cholera toxin recognition of $\mathrm{GM}_{1}$ receptors. Comparison of $2.5 \mathrm{mg} / \mathrm{mL}$ plant extract activities preventing the binding of subunit B of cholera toxin (white) and cholera toxin (gray) to immobilized $\mathrm{GM}_{1}$. Values are means \pm standard errors of six independent assays, $p<0.01$, compared with untreated CTX or CTB bound to receptors (100\%) for all data; * $p<$ 0.01 , for differential response of a plant extract on the binding of CTX or CTB to $\mathrm{GM}_{1}$

(Fig. 5a) and blackberry leaf (Fig. 5b) resulted in similar results as $\mathrm{GM}_{1}$. The application of raspberry leaf (Fig. 5c), rosehip (Fig. 5d) and wild strawberry leaf (Fig. 5e) extracts only partly decreased the fluorescence intensity of labeled cells. The standard DNA staining method, based on propidium iodide (PI), was used to determine the cytotoxic effect of plant extracts during this assay. The number of cells labeled with PI did not increase in the presence of any of the plant extracts, indicating that the plant extracts were not cytotoxic at the $2.5 \mathrm{mg} / \mathrm{mL}$ concentration for the fibroblast C688 cell line.

The inhibition of the CTB-FITC binding by plant extracts was observed by fluorescence microscopy (Fig. 6).
C688 cells were incubated for $1 \mathrm{~h}$ with CTB-FITC; next they were fixed to glass slides and observed under a fluorescence microscope. In cells treated only with CTBFITC, the CTB-FITC accumulated in the perinuclear region (Fig. 6f2, red arrow), mostly with the Golgi apparatus (Additional file 2). A similar, perinuclear localization of CTB-FITC is observed for cells incubated with rosehip at 2.5 (Fig. $6 \mathrm{~d} 1$ ) and $5.0 \mathrm{mg} / \mathrm{mL}$ concentrations, which suggests that lower concentrations of this extract do not suppress CTB binding and internalization. A higher concentration of rosehip extract $(10 \mathrm{mg} / \mathrm{mL})$ decreased the amount of toxin bound to the cell surface and suppressed its accumulation in the perinuclear region (Fig. $6 \mathrm{~d} 2$ ). The application of $2.5 \mathrm{mg} / \mathrm{mL}$ of agrimony (Fig. 6a2), blackberry leaf (Fig. 6b2) and wild strawberry leaf (Fig. 6e2) inhibited the CTB-FITC binding to the cell surface. Inhibition of CTB binding was also observed at $1.25 \mathrm{mg} / \mathrm{mL}$ for agrimony (Fig. 6a1). After incubation with $1.25 \mathrm{mg} / \mathrm{mL}$ of blackberry leaf (Fig. 6b1), CTB-FITC bound to the cell surface but did not accumulate in the perinuclear region. The same result was observed after incubation with $2.5 \mathrm{mg} / \mathrm{mL}$ raspberry leaf (Fig. 6, C1) and $1.25 \mathrm{mg} / \mathrm{mL}$ wild strawberry leaf (Fig. 6e1). Incubation with an increased $(5 \mathrm{mg} /$ $\mathrm{mL}$ ) concentration of raspberry leaf (Fig. 6c2) extract decreased the amount of toxin bound to the cell surface.

\section{Interactions between cholera toxin and plant extracts revealed by SDS-PAGE}

We used polyacrylamide gel electrophoresis to discriminate between stages 7 and 8 of Table 1. During electrophoresis under Tris/Tricine denaturing conditions, cholera toxin is separated into a $57 \mathrm{kDa}$ pentameric subunit $\mathrm{B}\left(\mathrm{B}_{5}\right)$, a 28 $\mathrm{kDa}$ subunit $\mathrm{A}$ and a small amount of $11.4 \mathrm{kDa}$ monomer subunit B (Fig. 7, lane 1). The application of: agrimony, blackberry leaf, raspberry leaf and wild strawberry leaf
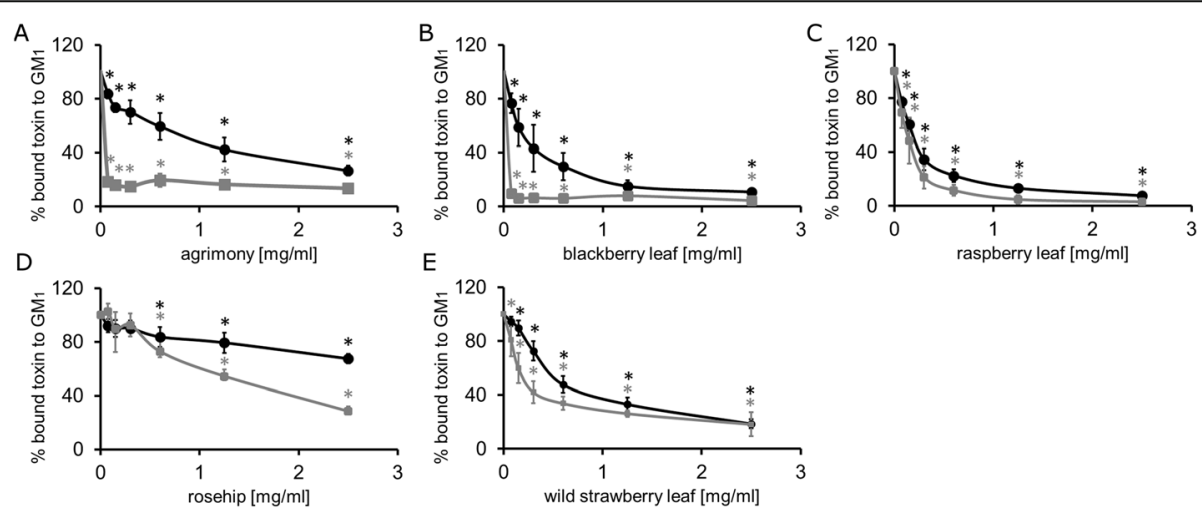

Fig. 4 Plant extract effects on the prevention of binding cholera toxin to immobilized GM. Modified ELISA binding assay showing the amount of

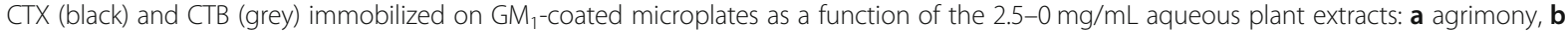
blackberry leaf, $\mathbf{c}$ raspberry leaf, $\mathbf{d}$ rosehip, e wild strawberry leaf. Values are mean \pm standard error of six independent assays. ${ }^{*} p<0.01$, compared with CTX or CTB (100\%) 
Table 5 Summary of beneficial plant extract effects ${ }^{a, b}$

\begin{tabular}{|c|c|c|c|c|c|c|c|}
\hline extract & $\begin{array}{l}\text { Blocking of CTX } \\
\text { binding to } \mathrm{GM}_{1} \\
(\mathrm{ELISA})^{\mathrm{cid}}\end{array}$ & $\begin{array}{l}\text { Blocking of CTB } \\
\text { binding to } \mathrm{GM}_{1} \\
(\text { ELISA) })^{\mathrm{cid}}\end{array}$ & $\begin{array}{l}\text { Blocking of } \\
\text { CTB binding } \\
\text { (cell assay) }\end{array}$ & $\begin{array}{l}\text { Blocking of CTB } \\
\text { internalization } \\
\text { (cell assay) }^{c}\end{array}$ & $\begin{array}{l}\text { Level of CAMP after } \\
\text { CTX and plant } \\
\text { extract treating }\end{array}$ & $\begin{array}{l}\text { Interaction with } \\
\text { CTX by SDS-PAGE }\end{array}$ & Pass $^{9}$ \\
\hline agrimony & 0.64 & $<0.08$ & 1.25 & 1.25 & 33 & aggregation & Yes \\
\hline blackberry leaf & 0.32 & $<0.08$ & 2.5 & 1.25 & 6.7 & aggregation & Yes \\
\hline raspberry leaf & 0.32 & 0.16 & No & 5.0 & 7.1 & aggregation & Yes \\
\hline rosehip & $>2.5^{9}$ & 1.25 & No & 10 & 35.8 & dissociation & Yes \\
\hline wild strawberry leaf & 0.64 & 0.32 & 2.5 & 1.25 & 9.7 & aggregation & Yes \\
\hline
\end{tabular}

${ }^{a}$ Entries in bold indicate positive effects at, or below, traditional doses

${ }^{\mathrm{b}}$ At least $50 \%$ Inhibition of harmful bacteria growth using traditional extract concentrations but no inhibition of beneficial $L$. rhamnosus

'Values in $\mathrm{mg} / \mathrm{mL}$ applied plant extract

Inhibition at least $50 \%$ toxin bound to ganglioside $\mathrm{GM}_{1}$

' $V$ alues in \% compared to untreated cells (100\%)

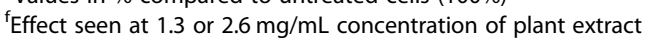

${ }^{9}$ May attain $50 \%$ inhibition of toxin with traditional doses in the $4-10 \mathrm{mg} / \mathrm{mL}$ range

extracts causes changes in the cholera toxin structure (Fig. 7a-c, e). At the highest extract concentrations, we observed the disappearance of all CTX components (lanes 3 and 4). With decreasing concentrations of plant extracts, the intensity of the subunit A band increased (lanes 5-8). The application of lower plant extract concentrations (0.06-0.0015, lanes: 6-8) resulted in the formation of aggregates (red arrow). To exclude background staining from the plant extracts, we applied samples with plant extract but without CTX (Fig. 7, lane 2).

To understand the mechanism of plant extract action, two known controls were used. The first control is based on the ability of gallic acid to inhibit cholera toxin internalization [19]. This polyphenol causes dissociation of СТВ into subunit B monomers (Fig. 7f, lanes: 3-5, blue arrow). In the second variant, CTX was inactivated by ganglioside $\mathrm{GM}_{1}$ in solution. These receptors effectively block the ganglioside binding site of cholera toxin and cause the aggregation of subunit B, marked by the red arrow on Fig. 7g in lanes: $3-5$. The intensity of the subunit A band does not depend on the $\mathrm{GM}_{1}$ concentration. Comparing the application of plant extracts and controls, two modes of action can be distinguished. All the plant extracts except rosehip have a mechanism of action similar to the $\mathrm{GM}_{1} / \mathrm{CTX}$ control where aggregation of the toxin blocks binding to the ganglioside receptors in human cells. In contrast, rosehip has a similar behavior as the gallic acid/CTX complex.

\section{Discussion}

Oral Rehydration Therapy (ORT) is commonly used and recommended by WHO for the treatment of acute diarrhea, including cholera. This therapy is based on solutions of oral rehydration salts (ORS) containing: glucose, sodium, chloride, potassium and citrate. ORT is used to protect the organism against dehydration caused by excessive fluid losses by vomiting and watery stools, but does not act against bacteria and their toxins [40]. The
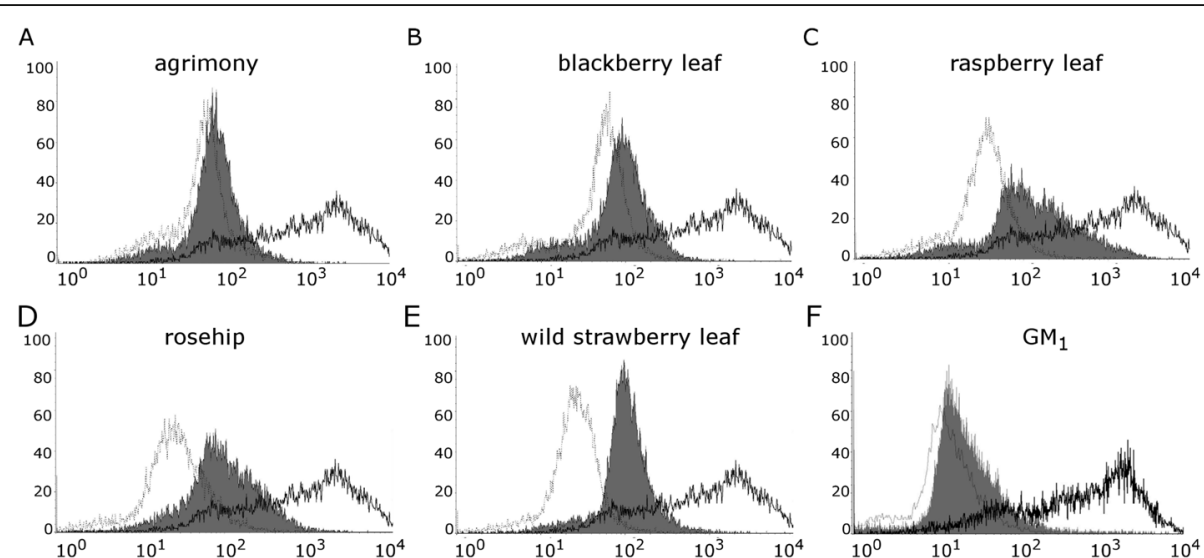

Fig. 5 Plant extract effects on the prevention of binding cholera toxin to cellular receptors. Flow cytometry assay showing the degree of labeled cells C688 after incubation with a mixture of $2.5 \mathrm{mg} / \mathrm{mL}$ plant extract and $0.25 \mu \mathrm{g} / \mathrm{mL}$ FITC-CTB, where the black trace represent cells treated only with CTB-FITC, and grey trace - cells treated only with plant extract and filled grey - cells treated with CTB-FITC and plant extract: a agrimony, $\mathbf{b}$ blackberry leaf, c raspberry leaf, $\mathbf{d}$ rosehip, e wild strawberry leaf and $\mathbf{f} \mathrm{GM}_{1}$ 


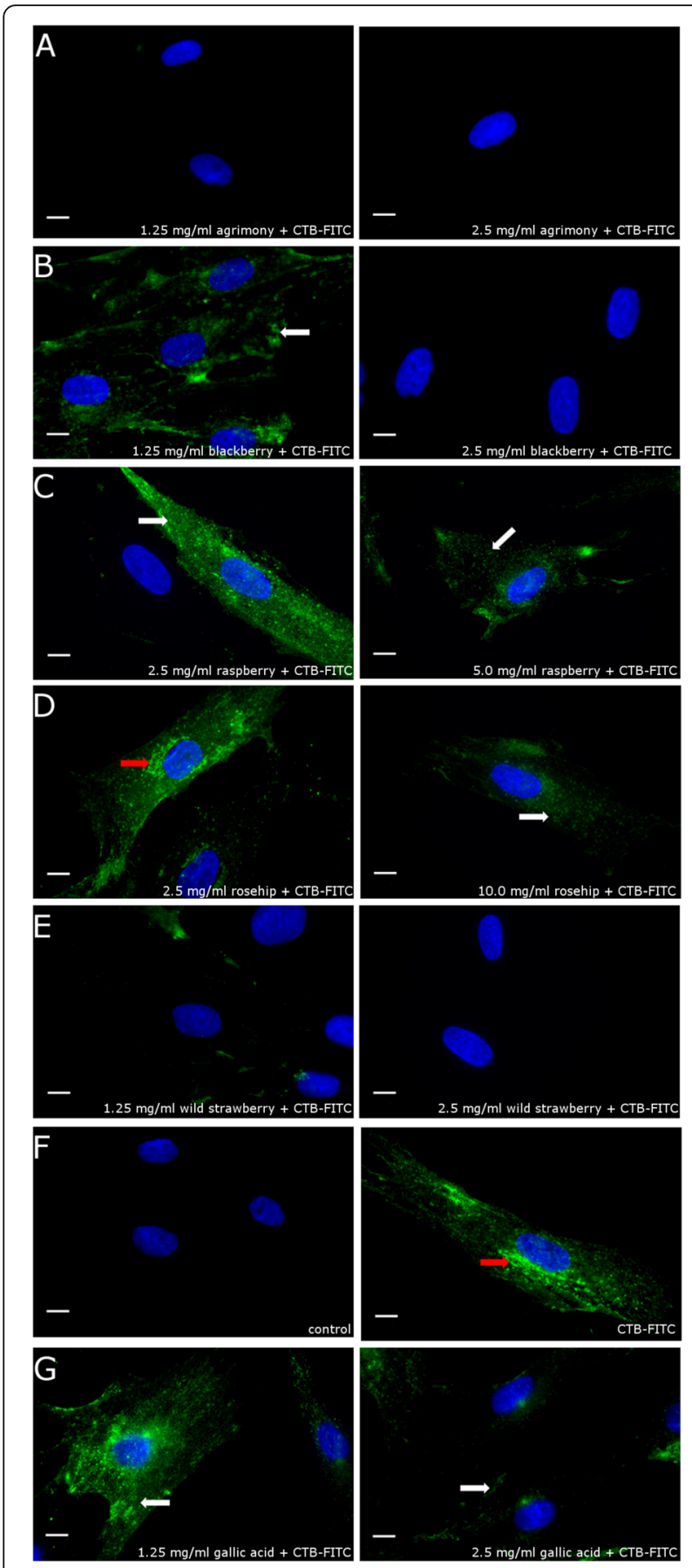

Fig. 6 Plant extract effects on the prevention of binding cholera toxin to cellular receptors or its internalization. Fluorescent microscope assay showing the CTB-FITC (green) labeling of fibroblasts after incubation with 2.5 and $1.25 \mathrm{mg} / \mathrm{mL}$ of: a agrimony, $\mathbf{b}$ blackberry leaf, $\mathbf{c}$ raspberry leaf, $\mathbf{d}$ rosehip; 2.5 and $10 \mathrm{mg} / \mathrm{mL}$, and e wild strawberry leaf; 2.5 and $5.0 \mathrm{mg}$ / $\mathrm{mL}$. As controls $\mathbf{f}$, we used (1) untreated cells and (2) incubated only with CTB FITC and $\mathbf{g}$ incubated with 1.25 or $2.5 \mathrm{mg} / \mathrm{mL}$ gallic acid, and CTB-FITC. The nuclei of the analyzed cells were stained by DAPI (blue). The red arrows show toxin accumulated in the Golgi apparatus (see Additional file 2 for co-localization with a Golgi marker), while white arrows show toxin bound to the cell surface. Scale bar is $10 \mu \mathrm{m}$ incorporation of plant extracts into ORS formulae can give several potential benefits such as providing a broad range of antimicrobial and anti-toxin compounds, as well as a taste that might be better accepted by young children, Table 1. On this basis, we investigated the properties of plant extracts used in Poland to treat nonspecific diarrhea.

The MTT assay and separate staining of C688 cells with PI indicated that the cytotoxicity of all the plant extracts was above $2.5 \mathrm{mg} / \mathrm{mL}$. Assuming that the traditional preparation generates similar extraction yields, Table 3, cytotoxic effects were observed above the traditional doses for all plant extracts except rosehip. The safe concentration for rosehip is calculated as $13 \mathrm{~g} / \mathrm{L}$ preparation compared with a traditional preparation of 10-53 g/L, Table 2. Overall, there appeared to be no correlation between various phytochemical analyses (phenolic or flavonoid contents, two antioxidant measures, Additional file 1) and the results of any of the antimicrobial or anti-toxin assays.

According to published data, agrimony [12], blackberry leaf [13] and raspberry leaf [13, 14] show a weak antimicrobial activity against $E$. coli strains. Our results are consistent with this data, Fig. 1. Specific, mild bacteriostatic potentials against $V$. cholerae were recorded for four of the plant extracts, Table 4, at or below concentrations used in traditional remedies. A bacteriostatic effect was measured just above the traditional preparation range for blackberry leaf. The specific growth inhibition may help beneficial bacterial colonies, for example L. rhamnosus that was unaffected by the plant extracts, compete with $V$. cholerae and delay the onset of diarrheal episodes. However, the bacteriostatic properties may contribute to asymptomatic carriers [41, 42]. Therefore, we cannot conclude if the bacteriostatic properties of the plant extracts are beneficial, or not, in a traditional cure of diarrhea related to cholera.

The toxic action of cholera toxin is related with the continuous production of CAMP, which leads to the opening of chloride channels and secretion of chloride anions [9]. To test if plant extracts prevent cAMP activation by CTX, the intracellular level of cAMP in cell cultures was measured. According to our data, all plant extracts suppressed the cholera toxin action on cAMP levels at levels below the traditional dose. This assay covers a broad number of stages in Table 1, as well as a number of intracellular steps for the internalization of the CTX through the endosomes, Golgi apparatus to endoplasmic reticulum and secretion to the cytoplasm. Several different assays were used to better define the action of the plant extracts.

Cell based assays (Figs. 5 and 6) utilizing CTB-FITC as a fluorescent marker provided results consistent with antibody detected CTB and CTX in the immobilized 


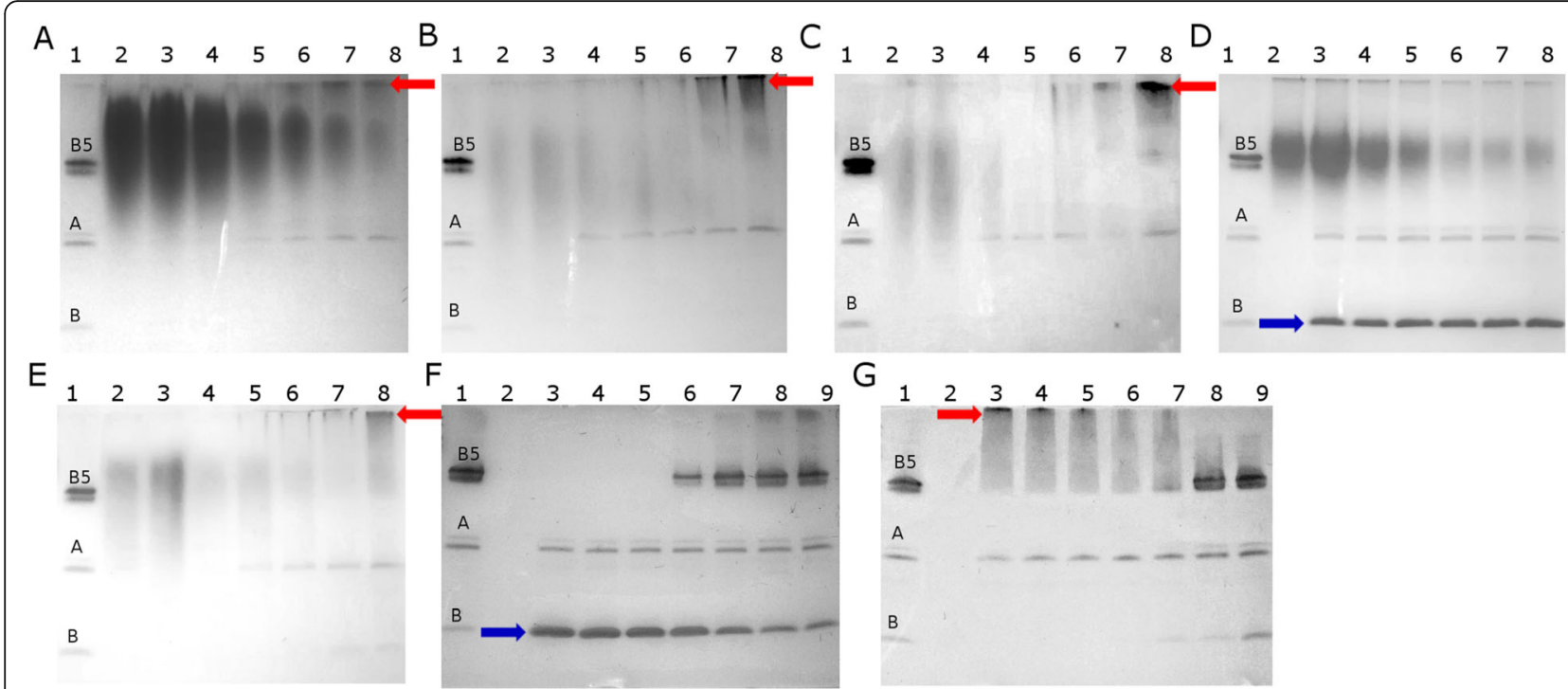

Fig. 7 SDS PAGE analysis of the interaction between cholera toxin and plant extracts. a agrimony, $\mathbf{b}$ blackberry leaf, $\mathbf{c}$ raspberry leaf, $\mathbf{d}$ rosehip, e wild strawberry leaf, $\mathbf{f}$ gallic acid control and $\mathbf{g} \mathrm{GM}_{1}$ control. For all panels, lane 1 contains $2 \mu \mathrm{g}$ CTX (dissociated into: $\mathrm{B}_{5}-57 \mathrm{kDa}, \mathrm{A}-28 \mathrm{kDa}$ and monomer $B-11.4 \mathrm{kDa}$ ), lane $2-1 \mathrm{mg}$ of plant extracts or $0.1 \mathrm{mg}$ gallic acid or $2 \mu \mathrm{g} \mathrm{GM}$. For panels (A-E), lanes 3-8 contain $2 \mu \mathrm{g} C \mathrm{CT}$ and: $1.0,0.5$, $0.25,0.125,0.06,0.03$ or $0.0015 \mathrm{mg}$ plant extract. For panel $\mathrm{F}$, lanes $3-8$ contain $2 \mu \mathrm{g}$ CTX and: $0.1,0.05,0.025,0.0125,0.006,0.003 \mathrm{or} 0.0015 \mathrm{mg}$ gallic acid. For panel $\mathrm{G}$, lanes $3-8$ contain $2 \mu \mathrm{g}$ CTX and: $2.0,1.0,0.5,0.25,0.125,0.06,0.03 \mu \mathrm{g} \mathrm{GM}$. The red arrow indicates aggregated protein, the blue arrow shows increased amount of monomer $\mathrm{B}$. The reaction volume was $12 \mu \mathrm{l}$ for all samples

$\mathrm{GM}_{1}$ assays in Figs. 3 and 4 , and the cAMP results (Fig. 2). Positive effects on the inhibition of CTB-FITC binding by plant extracts to C688 cells were observed. Two phenomena could be distinguished by flow cytometry and fluorescence microscopy. At higher plant extract doses, a lower labeling of C688 cells was reported by both methods. At intermediate levels, fluorescence microscopy revealed that while CTB-FITC labeled the C688 cells, the process of cellular internalization was probably blocked because CTB-FITC does not accumulate in the perinuclear region. With respect to flow cytometry data, blocking of cellular internalization would not be recognized as a positive effect of the plant extracts as the cells are still fluorescently labeled. Flow cytometry is a faster, more economical tool for screening plant extracts but may miss some beneficial plant extracts. Fluorescence microscopy adds detail to the flow cytometry data, perhaps accounting for the aggregation properties of some of the plant extracts revealed by native PAGE. High plant extract doses may fully aggregate the toxin and block the CTB/CTX recognition sites for $\mathrm{GM}_{1}$ receptors but intermediate plant extract concentrations may produce aggregates with remaining active $\mathrm{GM}_{1}$ binding sites that allow for cellular labeling. Regarding traditional levels, positive results were observed for low to mid traditional concentrations of agrimony and raspberry leaf. In the higher range of traditional concentrations, positive results were obtained for blackberry leaf and rosehip. Positive results for wild strawberry leaf were obtained only for concentrations greater than traditionally used.

Several plant extracts have been documented to interact with cholera-like toxins through different mechanisms. The Mexican plant Chiranthodendron pentadactylon Larrreat [31] and the Chinese plant Chaenomeles speciosa [43] can block the binding site of heat-labile enterotoxin produced by E. coli (LTX). The active compounds of these plants include gallic [19] oleanolic, ursolic and betulinic acids [43], and (-)-epicatechin [31]. These compounds bind to the toxin binding site for gangliosides $\left(\mathrm{GM}_{1}\right.$ and others), and thus cause toxin inactivation by competition. It was also shown that plant polyphenols, such as applehenon from apples, reduced the amount of cholera toxin bound to receptors and suppressed toxin internalization, probably by toxin aggregation [18]. SDS-PAGE analysis reveals that agrimony, raspberry leaf, blackberry leaf and wild strawberry leaf extracts cause aggregation of the toxin. This mechanism appears similar as after incubation of the toxin with ganglioside $\mathrm{GM}_{1}$, Fig. 7. Probably, active compounds of agrimony, blackberry leaf and wild strawberry leaf bind to the cholera toxin and block the binding site or change the toxin conformation, suppressing its binding to $\mathrm{GM}_{1}$ in the ELISA and cell-based assays. The raspberry leaf active compounds also cause aggregation, but do not block toxin binding to the cell surface. However, according to fluorescence microscopy and cAMP data, it does inhibit toxin internalization. SDS-PAGE 
analysis showed that rosehip extract (at $10 \mathrm{mg} / \mathrm{mL}$ concentration) behaves like gallic acid, Fig. 7. It remains to be seen if the different effects of rosehip and the other tested extracts have a synergistic effect.

According to our data, all plant extracts inhibited CTB binding to $\mathrm{GM}_{1}$ more strongly than CTX. This effect might be related to the toxin structure. Possibly, when the CTA is bound to CTB, part of the CTB structure is masked by CTA against the plant extracts compound action. When the CTB is alone, it has larger, unprotected surfaces, which can be easily accessed by plant compounds that cause changes in toxin conformation and reduce the ability to bind to $\mathrm{GM}_{1}$. Another explanation is that the plant extract interacts with the fluorescent marker of CTB-FITC, reducing its fluorescent properties. Although we cannot define the exact mechanisms related to the different effects of CTB-FITC and CTX, our data do suggest that assays involving CTB-FITC alone may overestimate the inhibitory power of plant extracts and chemical compounds on cholera toxins.

In the context of universal ORT formulations, the plant extracts should be safe for all sections of society including children, the elderly and pregnant/lactating women, as well as people suffering with long-term diseases that are incompatible with certain foodstuffs (diabetic, allergic). Extracts of raspberry leaf, in addition to being used as traditional medicine for diarrhea, are also widely used during pregnancy. While some reports indicate that raspberry leaf extracts are safe during pregnancy [44] other reports sow doubts or caution [45, 46]. Strawberry leaf is listed as an emmenagogue in a thorough review of plant based remedies used as abortifactants, contraceptives and sterilizers [47] although the original citation [48] itself cites the emmenagogue use as being historical (Ostermann, V. (1894) La vita in Friuli, Vols. I, II. Reprinted 1974, Del Bianco Ed., Udine, Italy). While traditional medicine may have been used for several centuries, the lack of properly conducted medical studies precludes the incorporation of any of the plant extracts into a universal ORS formula without further safety studies.

The obtained results indicate that the traditional application of: agrimony, raspberry leaf, blackberry leaf, rosehip and wild strawberry leaf infusions in treating bacterial diarrhea might be effective against diseases related to $\mathrm{AB}_{5}$ enterotoxins, such as cholera. These plant extracts can inhibit bacterial growth, block the toxin binding to receptors, inhibit toxin internalization to the host cell and suppress cAMP overproduction (Table 5).

\section{Conclusions}

The results described in this paper suggest that the studied plant extracts can eventually be useful complements to established ORT to improve the treatment of cholera- like diarrhea. The tested extracts do not kill bacteria, but do slow their growth, which might assist other antibiotic therapies. Simple aqueous plant extracts can inhibit the binding of cholera-like toxins to receptors or block the toxin internalization results in suppressing cAMP overproduction and chloride secretion, which protects the organism against rapid dehydration. The mechanisms involving the interactions between CTB/CTX and the studied plant extracts appear to be different, involving toxin aggregation and toxin deactivation. The mechanisms of action of these plants are still under investigation and the identification of active compounds and testing for synergistic effects is planned. We applied a number of methods and found that assays based on the safer (to use in the lab) CTB may provide a greater number of positive results than assays based on the more specific CTX, while FACS may miss some positive plant extract effects compared to the more labor intensive fluorescence microscopy method. SDS-PAGE is a useful method for examining if a plant extract can induce the ejection of CTA toxin from CTX to leave benign CTB, which may still bind to human cells without inducing diarrhea.

\section{Additional files}

Additional file 1: Phytochemical characteristics of plant extracts (DOCX $20 \mathrm{~kb}$ )

Additional file 2: Co-localization of CTB-FITC and the Golgi Apparatus (DOCX 515 kb)

\section{Abbreviations}

$A B_{5}$ : Class of enterotoxins consisting of one $A$ subunit and 5 identical $B$ subunits; ANOVA: Analysis of variance test; ATP: Adenosine triphosphate; BSA: Bovine serum albumin; C688: Primary human fibroblast line;

CAMP: Cyclic adenosine monophosphate; CTA: Subunit A of cholera toxin; CTB: Subunit B of cholera toxin; CTX: Cholera toxin; DAPI: 2-(4-

Amidinophenyl)-6-indolecarbamidine dihydrochloride; DMEM: Dulbecco's Modified Eagle's Medium; ELISA: Enzyme-Linked Immunosorbent Assay; FACS: Fluorescence Activated Cell Sorting; FBS: Fetal bovine serum; FITC: Fluorescein isothiocyanate; GM : Ganglioside $\mathrm{GM}_{1}$; LT and LT-II: heat labile enterotoxins; MBC: Minimal bactericidal concentrations; $\mathrm{MH}$ : MuellerHinton broth; MQ: Milli-Q grade water (> 18 M 2 resistivity); MTT: 3-[4,5dimethylthiazol-2-yl]-2,5- diphenyltetrazolium bromide; $\mathrm{OD}_{600}$ : Optical density at 600 nm; ORT: Oral Rehydration Therapy; PAGE: Polyacrylamide Gel Electrophoresis; PBS: Phosphate buffered saline; PI: Propidium iodide; SDS: Sodium dodecyl sulfate

\section{Authors' contributions}

MK conducted the laboratory work, produced and tested plant extracts, obtained data and its analysis, as well as prepared the first draft of the manuscript and Figures IS was involved in the design, supervision and validation of the antimicrobial tests. SP was involved in the design, supervision and validation of cell culture based experiments. Together, MP and PG originally conceived the project and designed, supervised and validated the biochemical experiments. PG oversaw the manuscript preparation and acted as general coordinator. All authors read and approved the manuscript.

Funding

M.K. thanks the National Science Centre, Poland for the PRELUDIUM grant (2016/23/N/NZ1/02449). M.P. thanks the Fundaçao para a Ciência e a Tecnologia (FCT) for the postdoctoral grant (SFRH/BPD/65762/2009). We 
acknowledge FCT and POCl, with co-participation of the European Regiona Development Fund (FEDER), for financial support under project PTDC/QUIBIQ/ 115298/2009. Grant N. 530-8725-D496-17 (Ministry of Science and Higher Education in Poland) funded part of the research. S.P. acknowledges the statutory grant for the Nencki Institute of Experimental Biology funded by the National Science Centre, Poland.

\section{Availability of data and materials}

The datasets used and/or analyzed during the current study are available from the corresponding author on reasonable request.

\section{Ethics approval and consent to participate}

Not applicable.

\section{Consent for publication}

Not applicable.

\section{Competing interests}

The authors declare that they have no competing interests.

\section{Author details}

'Laboratory of Biochemistry of Lipids, Nencki Institute of Experimental Biology, 3 Pasteur Street, 02-093, Warsaw, Poland. '2Laboratory of Molecular Interactions and NMR, Instituto de Tecnologia Química e Biológica, Av. da República, 2780-157 Oeiras, Portugal. ${ }^{3}$ Department of Molecular Biotechnology, Chemistry Faculty, University of Gdansk, 63 Wita Stwosza Street, 80-308 Gdańsk, Poland. ${ }^{4}$ Department of Drug Biotechnology and Bioinformatics, National Medicines Institute, 30/34 Chełmska Street, 00-725 Warsaw, Poland. ${ }^{5}$ Department of Biomedicinal Chemistry, Chemistry Faculty, University of Gdansk, ul. 63 Wita Stwosza Street, 80-308 Gdańsk, Poland.

\section{Received: 15 June 2018 Accepted: 3 June 2019}

Published online: 20 June 2019

\section{References}

1. Sánchez J, Holmgren J. Virulence factors, pathogenesis and vaccine protection in cholera and ETEC diarrhea. Curr Opin Immunol. 2005;17: 388-98.

2. World Health Organization. Number of suspected cholera cases reaches 100 000 in Yemen. UNICEF/WHO media cent; 2017. p. 1-2. https://www.who.int/ en/news-room/detail/08-06-2017-number-of-suspected-cholera-casesreaches-100-000-in-yemen

3. Kisiel M, Zacharska H, Czerniawska-Ankiersztejn M, Rudas D. The case of infection Vibrio cholerae non 01 non 0139 in Warsaw summary. Przegl Epidemiol. 2006;60:779-87.

4. Stypulkowska-Misiurewicz H, Stasiak J, Janczyk M, Tomaszewska E, Pancer K. Vibrio cholerae non-01 isolated in Poland from the bug river. Przeg Epid. 1995:49:237-43

5. Stypulkowska-Misiurewicz H, Pancer K, Roszkowiak A. Two unrelated cases of septicaemia due to Vibrio cholerae non-01, non-0139 in Poland, July and august 2006. Euro Surveill. 2006;11:E061130.2.

6. Rasko DA, Webster DR, Sahl JW, Bashir A, Boisen N, Scheutz F, et al. Origins of the E. coli strain causing an outbreak of hemolytic-uremic syndrome in Germany. N Engl J Med. 2011:365:709-17.

7. Schauder S, Shokat K, Surette MG, Bassler BL. The LuxS family of bacterial autoinducers: biosynthesis of a novel quorum-sensing signal molecule. Mol Microbiol. 2001;41:463-76.

8. Spangler BD. Structure and function of cholera toxin and the related Escherichia coli heat-labile enterotoxin. Microbiol Rev. 1992;56:622-47.

9. Wernick NLB, Chinnapen DJF, Cho JA, Lencer WI. Cholera toxin: an intracellular journey into the cytosol by way of the endoplasmic reticulum. Toxins (Basel). 2010;2:310-25

10. Brijesh S, Daswani P, Tetali P, Antia N, Birdi T. Studies on the antidiarrhoeal activity of Aegle marmelos unripe fruit: validating its traditional usage. BMC Complement Altern Med. 2009:9:47

11. Watt K, Christofi N, Young R. The detection of antibacterial actions of whole herb tinctures using luminescent Escherichia coli. Phytother Res. 2007;1199: 1193-9.

12. Muruzović M, Mladenović KG, Stefanović OD, Vasić SM, Čomić LR. Extracts of Agrimonia eupatoria L. as sources of biologically active compounds and evaluation of their antioxidant, antimicrobial, and antibiofilm activities. J Food Drug Anal. 2016:24:539-47.

13. Denev P, Kratchanova M, Ciz M, Lojek A, Vasicek O, Blazheva D, et al. Antioxidant, antimicrobial and neutrophil-modulating activities of herb extracts. Acta Biochim Pol. 2014;61:359-67.

14. Rauha J-PP, Remes S, Heinonen M, Hopia A, Kähkönen M, Kujala T, et al. Antimicrobial effects of Finnish plant extracts containing flavoniods and other phenolic compounds. Int J Food Microbiol. 2000;56:3-12.

15. Ng WL, Perez L, Cong J, Semmelhack MF, Bassler BL. Broad spectrum proquorum-sensing molecules as inhibitors of virulence in vibrios. PLoS Pathog. 2012:8:e1002767.

16. Chatterjee S, Asakura M, Chowdhury N, Neogi SB, Sugimoto N, Haldar S, et al. Capsaicin, a potential inhibitor of cholera toxin production in Vibrio cholerae. FEMS Microbiol Lett. 2010;306:54-60

17. Yamasaki S, Asakura M, Neogi SB, Hinenoya A, Iwaoka E, Aoki S. Inhibition of virulence potential of Vibrio cholerae by natural compounds. Indian J Med Res. 2011:133:232-9.

18. Morinaga N, Iwamarul Y, Yahiro K, Tagashira M, Moss J, Noda M. Differential activities of plant polyphenols on the binding and internalization of cholera toxin in vero cells. J Biol Chem. 2005;280:23303-9.

19. Chen J-C, Ho T-Y, Chang Y-S, Wu S-L, Hsiang C-Y. Anti-diarrheal effect of Galla Chinensis on the Escherichia coli heat-labile enterotoxin and ganglioside interaction. J Ethnopharmacol. 2006;103:385-91.

20. Morinaga N, Yahiro K, Noda M. Resveratrol, a natural polyphenolic compound, inhibits cholera toxin-induced cyclic AMP accumulation in Vero cells. Toxicon. 2010:56:29-35.

21. Tradtrantip L, Ko E-A, Verkman AS. Antidiarrheal efficacy and cellular mechanisms of a Thai herbal remedy. PLoS Negl Trop Dis. 2014;8:e2674.

22. Pieścik-Lech M, Szymański H, Szajewska H. Efficacy and safety of a new apple-flavoured oral rehydration solution in children with acute gastroenteritis: a double-blind randomized controlled trial. Acta Paediatr. 2012;101:e458-64.

23. Komiazyk M, Palczewska M, Sitkiewicz I, Groves P. Use of plant extracts to control and treat AB 5 enterotoxin-related diarrhea. Pol J Microbiol. 2014;63:3-14.

24. Chrubasik C, Roufogalis BD, Müller-Ladner U, Chrubasik S. A systematic review on the Rosa canina effect and efficacy profiles. Phytother Res. 2008; 22:725-33.

25. EMEA. Community herbal monograph on Rubus idaeus L., folium community herbal monograph on Rubus idaeus L., folium. Eur Med Agency. 2014. https:// www.ema.europa.eu/en/documents/herbal-monograph/final-communityherbal-monograph-rubus-idaeus-I-folium_en.pdf.

26. EMEA. Assessment report on Agrimonia eupatoria L., Herba. 2014. https:// www.ema.europa.eu/en/documents/herbal-report/draft-assessment-reportagrimonia-eupatoria-I-herba_en.pdf.

27. Mikołajczyk K, Wierzbicki A. Poznajemy zioła. Warsaw: Chemil; 1989

28. Olechnowicz-Stepien W, Lamer-Zarawska E. Rośliny lecznicze stosowane u dzieci. Warsaw: Państwowy Zakład Wydawnictw Lekarskich; 1986.

29. Barua D. History of cholera. Barua D, Greenough III WB, editors. Cholera. New York: Plenum Medical Book Company; 1992

30. Woś M, Szczepanowska J, Pikuła S, Tylki-Szymańska A, Zabłocki K, Bandorowicz Pikuła J. Mitochondrial dysfunction in fibroblasts derived from patients with Niemann-pick type C disease. Arch Biochem Biophys. 2016;593:50-9.

31. Velázquez C, Correa-Basurto J, Garcia-Hernandez N, Barbosa E, Tesoro-Cruz E, Calzada S, et al. Anti-diarrheal activity of (-)-Epicatechin from Chiranthodendron pentadactylon Larreat: experimental and computational studies. J Ethnopharmacol. 2012;143:716-9.

32. Schägger $H$, von Jagow $G$. Tricine-sodium dodecyl sulfate-polyacrylamide gel electrophoresis for the separation of proteins in the range from 1 to 100 kDa. Anal Biochem. 1987;166:368-79.

33. Kraus D. Consolidated data analysis and presentation using an open-source add-in for the Microsoft excel ${ }^{\circledR}$ spreadsheet software. Med Writ. 2014;23:25-8.

34. Ainsworth EA, Gillespie KM. Estimation of total phenolic content and other oxidation substrates in plant tissues using Folin-Ciocalteu reagent. Nat Protoc. 2007:2:875-7.

35. Pękal A, Pyrzynska K. Evaluation of aluminium complexation reaction for flavonoid content assay. Food Anal Methods. 2014;7:1776-82.

36. Sun J, Wang X, Wang P, Li L, Qu W, Liang J. Antimicrobial, antioxidant and cytotoxic properties of essential oil from Dictamnus angustifolius. J Ethnopharmacol. 2015;159:296-300.

37. Mishima H, Sears M, Bausher L, Gregory D. Ultracytochemistry of choleratoxin binding sites in ciliary processes. Cell Tissue Res. 1982;223:241-53. 
38. Blank N, Schiller M, Krienke S, Wabnitz G, Ho AD, Lorenz HM. Cholera toxin binds to lipid rafts but has a limited specificity for ganglioside GM1. Immunol Cell Biol. 2007;85:378-82.

39. Domon MM, Besson F, Bandorowicz-Pikula J, Pikula S. Annexin A6 is recruited into lipid rafts of Niemann-pick type $C$ disease fibroblasts in a $\mathrm{Ca}^{2}+-$ dependent manner. Biochem Biophys Res Commun. 2011;405:192-6.

40. UNICEF - World Health Organisation. Oral rehydration salts - production of the new ORS: UNICEF, World Health Organ; 2006. p. 1-123.

41. Tamayo JF, Mosley WH, Alvero MG, Joseph PR, Gomez CZ, Montague T, et al. Studies of cholera El Tor in the Philippines. Bull World Health Organ. 1965;33:645-9.

42. Lewnard JA, Antillón M, Gonsalves G, Miller AM, Ko Al, Pitzer VE. Strategies to prevent cholera introduction during international personnel deployments: a computational modeling analysis based on the 2010 Haiti outbreak. PLoS Med. 2016;13:1-23.

43. Chen J-C, Chang Y-S, Wu S-L, Chao D-C, Chang C-S, Li C-C, et al. Inhibition of Escherichia coli heat-labile enterotoxin-induced diarrhea by Chaenomeles speciosa. J Ethnopharmacol. 2007;113:233-9.

44. Parsons $\mathrm{M}$, Simpson M, Ponton T. Raspberry leaf and its effect on labour: safety and efficacy. Aust Coll Midwives Inc J. 1999;12:20-5.

45. Holst L, Haavik S, Nordeng H. Raspberry leaf - should it be recommended to pregnant women? Complement Ther Clin Pract. 2009;15:204-8.

46. Cheang KI, Nguyen TT, Karjane NW, Salley KES. Raspberry leaf and hypoglycemia in gestational diabetes mellitus. Obstet Gynecol. 2016;128:1421-4.

47. Kumar D, Kumar A, Prakash O. Potential antifertility agents from plants: a comprehensive review. J Ethnopharmacol. 2012;140:1-32.

48. Lokar LC, Poldini L. Herbal remedies in the traditional medicine of the Venezia Giulia region (north East Italy). J Ethnopharmacol. 1988;22:231-79.

\section{Publisher's Note}

Springer Nature remains neutral with regard to jurisdictional claims in published maps and institutional affiliations.

Ready to submit your research? Choose BMC and benefit from:

- fast, convenient online submission

- thorough peer review by experienced researchers in your field

- rapid publication on acceptance

- support for research data, including large and complex data types

- gold Open Access which fosters wider collaboration and increased citations

- maximum visibility for your research: over $100 \mathrm{M}$ website views per year

At $\mathrm{BMC}$, research is always in progress.

Learn more biomedcentral.com/submissions 